\title{
THE PLACE-NAMES OF VAN BUREN COUN'IY, IOWA
}

\author{
By T. J. Fitzpatrick \\ University of Nebraska, Lincoln, Neb.
}

(Continued from the July Number)

Mouxt Zion. A station on the Chicago, Rock Island and Pacific Railway in the southeastern part of section 7 of Van Buren Township. The site was laid out in March, 1860, by John and Alexander Taylor. The first name used for many years was Summit, a locally descriptive name as the site was on the divide. The present name is derived from Mount Zion, Palestine. The local Methodist Episcopal church was probably dedicated Mount Zion after which the village was directly named. Haskell's map, 1876, indicates Summit as being about a mile southeast of Mount Zion, that is the two places were separate entities.

The post office of Nount Zion, Van Buren County, Iowa, was established on July 26, 1861, with the appointment of Alfred J. Purviance, postmaster. His successors were: George W. Miller, October 29, 1866 ; J. W. Ogilbie, June 10, 1870; George W. Miller, May 6, 1870; Jacob J. Frazee, April 4, 1881; William Ager, January 31, 1883; Thomas E. Campbell, April 29, 1893; Frank L.. Moore, June 3, 1897; Anna E. Johnson, January 7, 1898; Joseph M. Freshwater, May 3, 1902; Joseph H. Wiley, December 26, 1902; Anna M: Nelson, September 7, 1918; Clay H. Bell, September 27, 1920; and Archibald S. Williams, September 15,1921 , who was still serving in 1929 .

Movis Zios. A rural church in the southeastern part of north section 18 of Des Moines 'Township, at the cross highways, about a mile cast and three miles north of the village of Cantril. It was so dedicated. in memory of the biblical name, Mount Zion, the name of the highest hill of Jerusalem, Palestine. Zion is from the Hebrew Tsiyon, meaning sunny; that is, a sunny place or a sunny mountain.

Movnt Zion. A rural school along State Highway Number 1, on the east side of the norticast quarter of section 7 of Vin Buren Township, over a half mile north of the town of Mount Zion and about a quarter of a mile south of the rural Presbyterian churcli also known as Mount Zion. The name of the school is for the nearby town.

Mun Cresk. The locally descriptive name of a small stream rising in the southwestern part of section 27 of Cedar Township, in the vicinity of Frog Pond rural school, runs southeastward and enters Henry County on the east side of section 36 of Cedar Township, Van Buren County.

Mud Crirk. A small stream rising in the southeastern part of section 14 of Henry Township, flows east and northeast to the Des Moines River near the northastern corner of section 18 of Bonaparte Township. The name is locally descriptive.

Napoleox. A projected, early village along the south side of the 
Des Moines River opposite the village of Bonaparte. The site was in the northern part of section 17 of Bonaparte 'Township. The village was named for Napoleon Bonaparte, emperor of France. It failed of permanency. The word Napoleon comes from the Greek language and means lion of the forest dell. About ten places in the United States have been named Napoleon. None has ever become more than a village; some are extinct. .

New Lexingron. A pioneer town and post office in existence before 1840 on the south side of section 7 of Bonaparte Township, about a mile west of where Bonaparte now stands. 'The development of Bonaparte sapped the vitality of New Lexington and the village site lapsed into a farm. ${ }^{30}$ The site was near the mouth of Lexington Creek which carries the name of the early village. The name New Lexington was in contradistinction to another pioneer village situated about eight miles farther up the Des Moines River near the mouth of Rock Creek. Jesse Williams' map, 1840, places Lexington on the site of New Lexington, a short distance east of the mouth of Lexington Creek.

The post office was established as New Lexington, Wisconsin Terri- tory, on April 6, 1837 (later changed to Iowa Territory) with William Fallis, postmaster. His successors were: Robert Moffett, November 30, 1837; John Cox, October 2, 1839; Thomas J. Cox, September 16, 1840 , who served until January 19, 1842, when the office was moved to the village of Bonaparte and given the same name under a new appointment.

New Market. This was another name for the pioneer village of Black Hawk City, which was located in section 7 of Village Township, across the Des Moines River from Iowaville. New Market was founded in 1848 by Andrew J. Davis and the buildings were torn down in 1861 . As Iowaville began in 1838 the name New Market was locally descriptive. See Black Hawk City.

The post office of New Market, Van Buren County, Iowa, was established March 14, 1850, with the appointment of Andrew J. Davis, postmaster. His successors were: Calvin P. Davis, June 30, 1852; David Doud, Jr., April 23, 1860; and Andrew J. Davis, March 6, 1863, who served until the office was discontinued January 14, 1865.

Niles. This is a station on the Chicago, Burlington and Quincy Railroad in the southeastern part of section 5 of Des Moines Township. The village was laid out in $\mathbf{1 8 5 5}$.

The post office of Niles, Van Buren County, Iowa, was established April 12, 1860, with the appointment of Henry King, postmaster. His successor was William A. Blizzard, February 14, 1868, who served until the office was discontinued on March 9, 1874.

The hamlet of Niles, Iowa, was probably named for John Milton Niles (1787-1856), an American journalist and statesman of Connecticut. He studied law and was admitted to the bar in 1817. The same year he established the Hartford Times which he managed for many

\footnotetext{
30Annals of Iowa, Third Series, Vol. XIII, p. 443.
} 
years. In 1835 he was appointed U. S. senator, serving four years. In 1840 he was appointed postmaster general by President Van Buren, serving about a year. In 1842 he was elected to the U. S. Senate, serving until 1849. In $185 \mathrm{~L}$ he went to Europe. He wrote numerous works, as lives of Perry, Lawrence, Pike, and Harrison; histories of South America and Mexico, etc.

NiLes. A rural school at the forks of the highway in the south central part of section 5 of Des Moines Township in the vicinity of Niles Station. 'The school district, Number 3, has the same name, Niles.

Nixox. The name of a rural school of district Number 2 in the west central part of the northwestern quarter of section 10 of Harrisburg Township, nearly two miles north of the Harrisburg Baptist Church. It was named after an early settler, probably Isaac Nixon, whose daughter, Mary Nixon Keck, was a resident of the vicinity; possibly for Samuel Nixon, a prominent farmer of section 31 of Cedar Township.

Nortif Lebayox. The name of a rural school on the west side of section 36 of Chequest Township in district Number 5, about threefourths mile north of the hamlet of Lebanon. The name is locally descriptive, being north of Lebanon. The school district also has the name North Lebanon for the same reason as the school.

Nortu Star. A rural school of district Number 10 on the north side of section 32 of Harrisburg l'lownship, near Coates (Honey) Creek, about three miles north of the village of Bonaparte. The school is on rising ground, facing the north, which situation probably suggested the name. 'The schoolhouse site is on the north side of "Honey Creek" stock farm of Max. Mahler.

OAk Gnovs. The name of a rural church in the southwestern part of section 33 of Lick Creek 'Township, three-fourths mile north and three miles west of the village of Kilbourne. It receives its name from the grove of oak trees in the vicinity of the church.

OAk. HinL. 'The name of a rural school at the forks of the highway: near the east side of section 3 of Farmington Township, about a mile southwest of the village of Farmington. A rising piece of ground in the vicinity covered by an oak grove seems to have suggested the name.

OAkLaxd. A laid-out site in Washington Township, adjoining Bentonsport on the south side. It was surveyed September 9, 1857; Samuel E. and Mercy C. Payne, proprietors. The name is more or less locally descriptive.

OA. Poine. A locally descriptive name for a rural post office in the northeastern part of section 5 of Jackson Township. The post office has long since been discontinued.

The post office of Oals Point, Van Buren County, Iowa, was established June 29, 1849, with the appointment of David Mowrie, postmaster. His successors were William Edmonson, June 15, year illegible, possibly 1865; John C. Edmonson, November 16, 1866; William F. Edmonson, December 10, 1872, and Barnet Bonar, May 6, 1880, under whom the office was discontinued June 23, 1880. 
Olive Braxch. The biblical name of a rural school in district Number 5 in the west central part of the north section 10 of Jackson Township, near the headwaters of an affluent of Fox River.

Palestine. The biblical name of a pioneer place south of the Des Moines River. In early days it was extensively promoted but failed of permanency. According to Jesse Williams' map, 1840, the site was in the northeastern corner of section 17 of Bonaparte 'Township, thus nearly opposite the town of Bonaparte.

Pameko. A pioneer post office represented on Henn, Williams \& Co.'s map of 1855 as being near where Selma now is. Parker, in The Iowa Handbook, 1856, also for 1857, page 180, gives the name as Pameka.

The post office of Pameko, Van Buren County, Iowa, was established June 9,1854 , with the appointment of Adam H. Young, postmaster. His successors were: Frederick A. Stump, May 21, year undecipherable, 1855 or 1856; and William H. Morgan, January 30, 1857, who served until the office was discontinued the following May 21, 1857.

Parkersvinle. 'The name of a place indicated on Jesse Williams' map of Iowa, 1840, as being in the northwestern part of section 17 of Union Township. The site was about a mile southeast of the village of Birmingham. The place was probably named for Samuel Parker, an early pioneer of Van Buren County, and a member of the first session of the territorial House of Representatives of Iowa. Later he became a resident of Oregon. Parkersville was still indicated as late as 1858 on geological map of the eastem half of the state of Iowa, 1857, published volume 1, part 1, of Hall's Geological Survey of Iowa, 1858.

Philadelpira. An early pioneer village in the southeast corner of section 2 of Lick Creek Township, near or by the Des Moines River, at the site of an Indian camp and in the vicinity (west) of the mouth of Lick Creek. It was founded in July, 1839, by John Patchett, and named Philadelphia, apparently after the city in Pennsylvania. This name it retained for many years and then was changed to Kilbourne, which see. Colton's map, 1844, erroneously indicates Philadelphia near where Pittsburg now is.

Pishceville. An inland hamlet in the northwestern corner of section 18 of Harrisburg Township, extending into the southeastern corner of section 12 of Washington Township. It was laid out August 25, 1855, by Roswell $T$. and Horace Dibble. A post office was carly established which continued for many years. It was probably named for Franklin Pierce (1804-1869), fourteenth president (1853-1857) of the United States, and who was president at the time of the naming.

The post office of Pierceville, Van Buren County, Iowa, was established February 22, 1865, with the appointment of West C. Walker, postmaster, who served until the office was discontinued June 29, 1869. The post office was re-established October 14, 1869, with the appointment of William Gaddis, postmaster, who served until June 30, 1884, when the office was again discontinued. The office was again re-established 
April 19, 1886, with John T. McLain, postmaster. The successors were: George C. Mendenhall, March 2, 1887; Elmer E. Rowe, April 27, 1889; Henry Dumn, December 28, 1889; Joln A. Morris, March 20, 1902, who served until the office was finally discontinued March 31, 1903.

Pronere. The name of a rural school in the southwestern part of section 17 of Vernon Township, nearly four and a half miles north of the village of Mount Sterling. The name Pioneer was doubtless given the school in recognition of its early establishment. The school district Number 7 is also known as Pioneer. It comprises sections 17 to 20 and three-fourths of $\mathbf{1 6 .}$

Prtrsburg. The site of this village is on the west side of the Des Moines River, adjacent to the mouth of Chequest Creek, and in section 27 of Van Buren Township. It was founded in March, 1839, by Ephraim Warner, A. B. Williams and John Groom. A post office was early established with Cyrus Gibson postmaster. A mill was built in the vicinity in 1836 . The village prospered for many years, but as the railroads missed the place it declined after 1870 . It was named for Pittsburg, Pennsylvania. The original name was Rising Sun. Portions of the original plat of the town were vacated by an act of the legislature approved January 13, 1849. The early spelling of the Iowa village was "Pittsburgh."

The post office of Pittsburg, Van Buren County, Iowa, was established as Rising Sun January 11, 1840, with the appointment of Cyrus Gibson, pastmaster, and under whom the name of the office was changed to Pittsburg June 13, 1844, with his reappointment. His successors were: Phineas M. Janny, August 29, 1845; George Kisinger, May 30, 1849; Archibald M. Donald, June 18, 1851; Thomas Rankin, June 16, 1853; Archibald M. Donald, April 19, 1854; Mark A. Newton, February 5, 1856; William Funk, December 30, 1850; Meshack Kent, July 7, 1857; 'Thomas Rankin, March 16, 1860; James C. Claypool, May 19, 1862; Boyleston S. Wilson, March 30, 1866; Joshua H. Duffield, October 9, 1868; John C. Smith, April 14, 1870; John M. Bonner, September 9, 1875; John C. Smith, February 2, 1877; L. S. Funk, $\Lambda$ pril 20, 1877; Voltaire P. 'Iwombly, July 20, 1877; Joshua H. Duffield, April 16, 1878; Charles M. Johnston, February 28, 1879; George W. Lewis, March 18, 1880; O. S. Wilkins, March 28, 1881; James M. Elerick, May 9, 1888, and James B. Stong, July 5, 1892, who served until the office was discontinued March 31, 1903.

The Plat Book, 1897, page 34, has the legend "Pittsburg originally 'Troy located in Van Buren township."

Plensant Hir.t. This village is across the Des Moines River and south from Keosauqua, in section 36 of Van Buren Township. It was founded March 20, 1850, by John Purdom. It may be considered a suburb of Keosauqua. The name is more or less locally descriptive. It is now sometimes called South Keosauqua, a locally descriptive name. The neighborhood school district also has the name Pleasant Hill.

Pleasant Plain. A rural school in district Number 1 on the north 
side of the northeast quarter of section 11 of Village Township, three miles east and a mile north of the village of Selma. 'The name of the school is locally descriptive. The district comprises sections $1,2,11$ and 12.

Pumoutr. 'The village site was laid out on the north side of section 35 of Farmington Township adjoining Farmington on the north and by the Des Moines River. The place was founded April 26, 1842, by Edward and John Colton, and later promoted by Colonel Oliver H. P. Scott. A lock and dam were formerly here as well as a large flouring mill. The name derives from Plymouth, Massachusetts, which in turn was named for Plymoutli, England, at the mouth of the River Plym, hence the name. See Plat Book, 1897, page 10.

Portland. A village site was laid out in section 26 of Village Township, on the south side of the Des Moines River, opposite Doud's Station, and near the mouth of Holcomb Creek. It was founded in 1834 by Samuel Holcomb, Robert Leggett, David Maggard and others. In $184 \pi$ the plat was entered by John Alexander, Ira Claflin and O. S. Freeman, county commissioners. A post office was early established with Samuel M. Brice, postmaster ${ }^{31}$ It was directly or indirectly named for Portland, Maine, which in turn derived its name from Portland, England. Sometime in the eighties Portland, Iowa, was rechristened Leando.

According to G. G. Wright's Address, page 15, Portland was laid out in 1839 by John 'Tolman of Portland, Maine; thus directly naming the Iowa village after his old home place.

The post office of Portland, Van Buren County, Iowa, was established January 11, 1840, with the appointment of Samuel M. Brice, postmaster. His successors were: James S. Park, September 12, 1840; John M. Doud, October 19, 1846; Aaron Park, June 27, 1849; William H. Holcomb, December 12, 1849; John D. Woodworth, October 27, 1851; John P. Brown, April 29, 1855, and Eliab Doud, May 2, 1862, who served until the office was discontinued on August 9, 1864.

Ровтово. For nearly nine years the early name of the post office at Keosauqua, which see. The word is Spanish and means port or land of gold; used locally more in the sense of beautiful land or pleasant place, thus locally descriptive. The name is very unusual if not unique; not occurring in Lippincott's Qazetteer. The pioneers gave the name as Port Oro, but the U. S. Post Office Department records, though very illegible, indicate one word, as Portoro.

Potters Brancif. A small run risirg in the southwestern part of section 3 of Bonaparte 'lownship, runs southwest to the Des Moines River on the north side of section 16 of the same township, a short distance (nearly a mile) below (east) of the town of Bonaparte. The stream received its name from a nearby pottery factory which was

31 The History of Van Buren County, Iowa, 1878, page 503, erroncously gives the honor of being the lirst postmaster to James l'ork. This is a typouraphical error for James S. Park, who, however, was the second postmaster, nut the first. 
started in 1866. On some maps as Plat Book, 1897, page 4, the name is Potters Creek.

Pramiv Consins. The locilly descriptive name of a rural school on the highway in the east central part of section 26 of Cedar Township, in district Number 1.

Pranie Quves. The name of a rural school in district Number 2 in the northeastern corner of section 28 of Vernon Township. The name appears to be locally descriptive, the site heing on the prairie where formerly spiracas (prairie queen) bloomed. The irregular school district is also known as Prairie Queen.

The schoolhouse is in a rather elevated situation and has a belfry; scemingly in a commanding position on what was formerly a prairie. It has been asserted that because of these facts some one's fancy suggested the name Prairie Queen.

Providence. The name of a Baptist, rural church on the south side of section 9 of Chequest 'Township. Andreas' Atlas, 1875, gives the site one-fourth mile south, at the forks of the highway in the north central part of section 16. The church was so dedicated in recognition by the members of the guidance of divine providence in their affairs.

REv OAK. 'The name of a rural school on the west side of section 20 of Lick Creek 'Township, about two miles east and three-fourths mile north of the village of Douds Leando. The school receives its name from the grove of red oak trees (usually given as Quorcus rubra) in the vicinity. The school district Number 4 , comprising all or most of sections 17 to 20 , northern halves of 29 and 30, is also named Red Oak.

Reris Crefk. The stream rises by several branches on the eastern side of Harrisburg Township in sections 13, 14 and 15, flows southward and enters the Des Moines River near the center of section 15 of Bonaparte Township. It is almost the counterpart of Coates Creek except that it is more sinuous in its lower course. The name is probably local in origin, being for a resident of the vicinity, Samuel C. Reed, who settled in the neighborhood about 1835. Reed Creek is a frequent form of the name. ${ }^{32}$ The U. S. soil survey map, 1917, gives it as Reeds Creek, as does also Jesse Williams' map, 1840. An important affluent comes from Lee County, coursing westward in or near the southern part of section 12 of Bonaparte 'Township, reaching Reeds Creek near the line between sections 11 and 14 .

Ringe. 'The name of a rural school on the north side of section 11 of Chequest Township and of the school district Number 1, comprising sections 1, 2, 11 and 12 . The name is locally descriptive as the schoolhouse site and district are on the divide or ridge between the Des Moines River and Chequest Creek. 'The irregularly running road east and west through the district follows the summit of the divide and is known as the Ridge road.

Rising Sun. This was the early and original name for Pittsburgh, founcled in March, 1839. As the village site faced the east with an

\footnotetext{
32 Iowa Geol. Survey IV, p. 205.
} 
unobstructed view the name was locally descriptive. See Pittsburg. The name was changed from Rising Sun to "Pittshurgh" by an act of the legislature of the Iowa Territory, approved February 17, 1842.33

The most important place with the name Rising Sun is in southeastern Indiana on the north (locally west) bank of the Ohio River and is the county seat of Ohio County. Its situation is such as to suggest a locally descriptive name. At least five other places in the United States have been named Rising Sun. The name of the village in Iowa may have been in part at least for the town in Indiana.

Rochestrer. This place was laid out early in 1837 by M. D. Strong, J. S. Wells and William W. Corrill. On March 21, 1837, efforts were made to make it the county seat. The territorial legislature of Wisconsin passed an act declaring it the county seat but this was reconsidered and voted otherwise. The place now exists only in memory. It was probably named for Rachester, Indiana, Pennsylvania, or New York. Rochester, New York, was named for Colonel Nathaniel Rochester. Several towns in the United States are named Rochester, some of them for Rochester, New York, others for Rochester, England. According to Jesse Williams' map, 1840, the site of Rochester, Iowa, was on the north (locally west) side of the Des Moines River, near the center of section 29 of Van Buren Township, about two miles northeast of where the town of Keosauqua now is.

Rock Crefk. The name of a small stream in Cedar Township. It rises in the southern part of section 17, courses irregularly eastward and leaves Van Buren County in the southeastern part of section 13. The rocky bed of the creek gives the name to the stream, hence locally descriptive.

Rock CreEk. A small stream rising by two branches in the northeastern and northern part of section 4 of Washington Township, flows southward and empties into the Des Moines River near the center of section 21 of the same township. The name is locally descriptive, the creek having a rocky bed.

Rosser. The name of a rural school in district Number 7, north of Holcomb Creek, and on the east side of the southeast quarter of section 30 of Village Township. It was named for George N. Rosser, an early resident of the same section and owner of the land, including the school site. $^{34}$ The district comprises sections 29 to 32 , inclusive. Mr. Rosser was a representative in the Fifth, Fifth Extra and Thirteenth general assemblies of Iowa. He settled in the vicinity of the school in 1838 . $\mathrm{He}$ is credited with teaching in 1842 the first school in the neighborhood..$^{35}$

Russerl. The name of a rural school on the south side of the southeast quarter of section 30 of Chequest Township in district Number 7 . 'The school was named for a local resident, John Russell, on whose farm the schoolhouse site was located. The school district, comprising sec-

33 Laws of loura, 1841-42, p. 1c6.

34 Hist. of Van Buren Co., 1878, p. 539; Andreas' Atlas, 1875, p. 246.

35 Hist. of Van Buren Co., 1878, p. 496 . 
tions 29 to 32, was also named Russell. See Plat Book, 1897, page 8 .

Russei.t. The name of a rural school of district Number 8 at the cross highways in the northeastern corner of section 33 of Harrisburg 'lownship, over a mile east and three miles north of the town of Bonaparte. It was probably named for Adam Russell, an early resident and landowner in the southwestern part of section 27, in the inmediate vicinity of the school. The school district comprises sections $27,28,33$ and 34 .

Salem. The biblical name of a rural school on the south side of the southeast quarter of section 26 of Union Township, a mile north and a mile and a quarter west of the hamlet of Utica. The word Salem is derived from the Hebrew word Shalem, meaning peaceful.

Silubris. A pioneer village in the southeastern part of Farmington 'lownship, about two miles south of Farmington, near the state line. The promoter was Abner Kneeland who, with his followers, wished to leave puritanical Boston. The village was laid out about 1838 and existed for a number of years until disrupted by disagreements. Salubria is a derivative of salubrity, meaning salutary or healthful, the idea being to promote or contribute to some beneficent purpose as was anticipated by the colonists. There was never established in Van Buren County, Iowa, a post office with the name Salubria. There was a post village with this name in Ada County, Idaho.

Abner Kneeland was born in Gardner, Massachusetts, April 7, 1774. He was of Scotch ancestry. His schooling was quite limited, confined to the common schools of his native village and a single term in a distant academy. By his own efforts he became a good scholar, distinguished as a linguist, and acquired a reputation as a minister and a writer. About 1795 he resided for a short time at Dummerston, Vermont, working at the trade of a carpenter and teaching school. In 1803 he was licensed as a minister. He held the pastorate at Langdon, New Hampshire, 1805-1811, serving also in the House of Representatives, 1810 and 1811. Other pastorates held were Charleston, Mass., 1812-14; Whiteside, N. Y., 1817; Philadelphia, Pa., 1818-25; New York City, 1826-29, when he retired from ministerial work. In 1831 he founded a weekly paper in Boston. In 1834 he stood trial for blasphemy. The case was in various courts until 1838 when Kneeland was sentenced to sixty days' imprisonment. In 1839 he came to Van Buren County, Iowa, where he residerl, until his death, in the little hamlet he helped to found. In Iowa, Kneeland interested himself in developing his colony, constructing what was then a mansion, giving public lectures, and incidentally entered politiss, on two occasions running for office. He was away a short time teaching a term of school in Helena, Arkansas. His liberal views would now attract no particular resentment, but in his day were violently opposed by the supporters of what was then considered orthodoxy. Like most persecutions his was unwarranted. Kneeland was a man of sincerity, of marked ability, of pure morals, and with a gracious disposition. He died August 27, 
1844, aged 70 years, and was buried on his farm as was his fourth wife. In 1881 the remains of both were transferred to the cemetery at Farmington. Some of Knecland's descendants still reside in the vicinity of Salubria.

Seights Cnefk. A small stream, rising in the northern part of section 10 of Chequest l'ownship in the vicinity of Hawkeye school, runs north to Holcomb Creek in the central part of section 34 of Village Township. The stream was probably named for G. Seitz, an early resident in the vicinity of the stream in section 3 of Chequest Township. ${ }^{36}$

Selma. A station on the Chicago, Rock Island and Pacific Railway in sections 8 and 17 of Village Township, by the Des Moines River. Formerly the place was named Independent and the post office Hickory. Apparently the railroad changed the name to Selma and the post office adopted the same name. It was. probably named after Selma, Alabama, which is said to be named from the "Songs of Selma" in Ossian. See Independent.

The post office at Selma, Van Buren County, Iowa, was established under the name of Hickory, September 10, 1858, with the appointment of Eli Stump, postmaster. His successors were: George Stump, February 25, 1861; James M. McLane, July 16, 1861; John A. Bartholomew, February 27, 1865; Jacob T. Overturff, March 23, 1866; David C. Beaman, October 21, 1867; Frederick G. Adams, October 2, 1873, under whom the name of the office was changed to Selma, April 29, 1882, with his reappointment; Charles W. Finney, December 31, 1885; Frederick G. Adams, February 19, 1889; Henry W. Ritz, August 11, 1893; Mrs. Josie Stump, September 14, 1897, and Mary J. Stump, September 30, 1897, who was still serving in 1931.

George Stump was a pioneer of the vicinity. He entered a claim along Stump Creek, which was named for him. Eli Stump was his son. Mrs. Josie Stump and Mary J. Stump are the same person. Her full name is Mary Josephine Stump (nee Jackson). She is the widow of David Stump, who was one of the younger children of George and Mary Stump. A pparently one of the family, Frederick A. Stump, was postmaster of Pameko, an earlier post office in the vicinity of Selma.

SHERIDAN. The name af an early inland post office in or near section 29 of Cedar Township. The post office was doubtless named for General Philip Henry Sheridan (1831-1888).

'The post office of Sheridan, Van Buren County, Iowa, was established May 3, 1865, with appointment of James Stilwell, postmaster. He was succeeded by James H. Rockey, September 13, 1872, who served until the office was discontinued December 16,1874 . The office was reestablished January 22, 1875, with the appointment of James H. Rockey, postmaster. His successors were: Sarah M. Rockey, March 15, 1875, and William Askew, February 8, 1876, under whom the office was finally discontinued March 27, 1877.

36 Ibid., p. 557. 
Srguen's Milu. This mill is represented on Henn, Williams \& Co.'s maps of Iowa, 1854. and 1855, as being on the north bank of Cedar Creek, in or near the southern part of section 2 of Cedar Township. The mill was evidently named for the proprietor, probably M. Sigler, a pioneer resident of Van Buren County.

Sijver Lake. A former, rather large pond on the east side of the northeast quarter of south section 17 of Jackson Township, over four miles south and a mile east of the village of Milton. It is on Silver Lake stock farm which in 1897 was owned by Ida Bull and in 1918 by R. W. Barrow. See Plat Book, 1897, page 21, and Standard Allas, 1918, page 37 .

In pioneer days before much prairie had been broken the water in the pond was free of silt and reflections showed clearly, hence the name Silver Lake.

Sourm Fonk. A small creek, rising in the south central part of section 20 of Des Moines Township, runs eastwardly to Indian Creek in the central part of section 25 of the same township. The name is locally descriptive, the stream being south of Indian Creek.

Soutn Keosa Uqua. A site with this name was laid out February 19, 1840, by James Hall, the proprietor. A hamlet resulted which was later absorbed by Keosauqua. The name is locally descriptive. This place was on the north side of the Des Moines River and distinct from Pleasant Hill on the south side, also sometimes called South Keosauqua.

Soutu Labaxox. The name of a rural school on the west side of the southwest quarter of north section 1 of Jackson Township, three-fourths of a mile south of the hamlet of Lebanon. The school district Number 8 , comprising sections 1, 12, most of 2 and 11, is also called South Lehanon. The name of the school and district is locally descriptive, being south of Lebanon.

Sipexcer. The name of a rural school in the southwestern part of section 6 of Cedar 'lownship in district Number 6, two miles north of the village of Stockport. It was named for Absalom Spencer, an cmigrant from Kentucky and Indiana. He came to Van Buren County in the fall of 1841 and settled on the farm where the school was subsequently established. He died September 14, 1873, and was succeeded in the estate by his son, William, also a long-time resident of the community. ${ }^{37}$

Star. The name of a rural school near the west side of section 17 of Chequest Township in district Number 8. Andreas' Atlas, 1875, shows that the school site was formerly at the forks of the road in the center of the section, a site since owned by a church. The word star is frequently used as a local name and particularly for a rural school. The name is short and familiar and readily suggested by a star mail route or the phrase "the stars and stripes."

Stockrort. A station on the Chicago, Fort: Madison and Des Moines (now the Chicago, Burlington and Quincy) railroad in the southeastern

37 Ibid, p. 586 . 
part of section 13 of Union Township. The name is locally descriptive, the station being used for loading stock. ${ }^{38} A$ villagc has developed along the cross highways about the common corner of sections 18 and 24 of Union Township and 13 and 19 of Cedar 'Township.

Srone. The name of a rural school at the cross highways in the southeastern corner of section 6 of Harrisburg Township. It is situated at the center of joint district Number 3 which originally comprised most if not all of sections 5 to 8 . The school was so named because the schoolhouse was built of stone.

Strony Chapli. The name of a rural church at the forks of the highway near the center of section 25 of Vernon Township, about two miles north of Willits Station. It was named for John Story, an early resident of the same section, ${ }^{39}$ the chapel standing on the northeast corner of his farm. The cemetery is about one-fourth mile north. ${ }^{40}$

Stump Cneer. A small stream from Jefferson County, runs south across sections $\dot{5}$ and 8 of Village Township to the Des Moines River in - the south central part of section 17, nearly a mile south of the village of Selma. The stream was named for George Stump, an early settler and claim owner in the vicinity of the stream, the founder of the village of Independent, later known as Selma.

Stumptows. The local name given to the village of Independent, after George Stump, the proprietor. See Independent.

Summer Creve. This small stream rises in the southwestern part of section 2 of Union Township, with a branch from the south part of section 18 of Cedar Township. It runs east and north to Big Cedar Creek in the central part of section 4 of Cedar Township.

Summr. A site with this name was laid out in March, 1860, by John and Alexander Taylor in the southeastern corner of section 7 of Van Buren 'lownship. As the site was on high ground or divide it was given the locally descriptive name of Summit which was used for many years. Then the name was changed to Mount Zion, which see.

Sumrir. The name of a rural school in district Number 5, along the highway in the central part of south section 9 of Vernon Township, two miles east of the village of Mount Sterling. As the school site is on rising ground the name is locally descriptive. The school district, comprising south sections $3,4,9,10$, and east halves of 5 and 8 , is also known as Summit.

Swirns. A rural school located on the south side of section 5 of Van Buren Township, two miles west and three and a half miles north of the hamlet of Pittsburg. It was nimed for a local resident, Joseph Swiers, on whose firm the schoolhouse site is situated.

TAYlor. The name of a rural school of district Number 1 in the northwest part of north section 14 of Des Moines Township, about three

38 It was named for Stockport, England, by an English-born resident of the vicinity,-E.R.H.

39 Hist. of Van Buren Co., 1878, p. 548.

40 Plat Book of Van Buren COo., 1897, p. 30; Standard Atlas of Van Buren Co., 1918 , p. 26. 
miles southwest of the village of Keosauqua. It was probably named for S. Taylor, who resided nearby in section 15 . The school district also is named Taylor. ${ }^{11}$

'Thatcher's Creek. A small stream on the south side of the Des Moines River, opposite the town of Keosauqua. The two branches of the stream rise in section 12, flow northward and enter the Des Moines River on the east side of section 2 of Van Buren Township. It was probably named for Jonathan Thitcher, a millwright, born April 8, 1824, in Berkeley County, West Virginia. He went to Ohio in 1826 and to Van Buren County, Iowa, in the spring of 1839 . He was a representative in the Eleventh General Assembly of Iowa.

Tronas Jifrersos. The name of a rural school in the southwestern part of section 17 (on the line between sections 17 and 18) of Bonaparte 'lownship, nearly two miles southwest of the village of Bonaparte. The school received its name from admirers of Thomas Jefferson (17431826), third president (1801-1809) of the United States. In Plat Book, 1897, page 4, the schoolhouse site is represented as being in the southeastern part of section 18 .

Ton Paxer. The name of a rural school in the northwest corner of section 10 of Bonaparte Township, nearly two miles northeast of the town of Bonaparte. The name presumably is for Thomas Paine (17371809), the brilliant publicist of the American and French revolutions. In Plat Book, 1897, page 4, the school and district have the name Paine, which is the correct English spelling. 'Tom Payne is the spelling given by the U. S. soil map, 1917, the French form.

Tug Fonk. A short run rising in the western part of the north section 5 of Des Moines 'lownship, courses southeast to Indian Creek in the northern part of north section 16. See Plat Book, 1897, page 9.

Union. This township lies on the northern side of Van Burcn County, west of Cedar, north of Washington and Van Buren, and east of Lick Creek townships. It comprises congressional township 70 north, range 9 west. It was obviously named in harmony with prevailing sentiment then current, "union now and forever."

Union 'Lownship, Van Buren County, Iowa, was created by order of the Board of County Commissioners in the organizing session held January 6, 1841, with the present boundaries, and it was so named in the order. The official record reads: "Township 70 North in Range 9 west in said County is hereby organized and the last named Township is hereby named Union and the first meeting of the citizens of said 'Township shall be held at Winchester."

Union is a very popular name for townships, rural post offices, and district schools. Thousands of places in the United States, mostly minor, local ones, have this name alone or in combination. At least thirty-seven counties in Iowa have a Union township and sixteen states have a Union county.

\footnotetext{
41 There is also a Taylor School No. 1 in Cedar Townslip, one mile north and one-half mile east of the center of the township, named for the family adjacent. -E.R.H.
} 
Unios. Henn, Williams \& Co.'s map, 1855 , represents a post office with the name Union in or near south section 7 of Des Moines Township. Evidently the same office is indicated by Hall's Geological map of Iowa, 1857, as being about four miles westward in south section 9 of Jackson Township. Being a rural post office it was movable with a change of postmasters. It is also probable that these two maps are erroneous and that the next office was the one intended.

Union. A pioneer post office in or near section 34 of Union Township, obviously named for the township. See Henn, Williams \& Co.'s maps, 1854, 1855.

The post office of Union in Van Buren County, Iowa, was established October 7, 1847, with the appointment of John Tarbel, postmaster. His successors were: George Cupp, January 27, 1849, and William Daniels, August 2, 1852, who served until the office was discontinued, March 31, 1856.

Union. The name of a church on East Street in the hamlet of Upton on the block owned by the Upton I.iterary Society. The church is inter-denominational, hence the name. See Plat Book, 1897, page 10.

Unios. The name of a Methodist free church in the southern part of section 6 of Lick Creek Township.

Union. The name of a rural school at the cross highways in the northeastern corner of section 7 of Lick Creek Township in the neighborhood of Union Church. The school district Number 3, comprising all or most of sections 5 to 8 , is also named Union.

Unior Conners. This is the early name of the post office at Mount Sterling, which see. The name Union was in harmony with sentiment then prevailing and Corners was locally descriptive, being then whero three roads met.

Upron. An inland hamlet near the middle of section 17 of Des Moines Township, along the state line. It was founded $\Lambda$ pril 14, 1852, by John Upton, after whom the place was named. The school district, Number 6 , also has the name Upton after the village.

The post office of Upton, Van Buren County, Iowa, was established July 22, 1852, with the appointment of John Upton, postmaster. His successors were: Milton Heving, March 23, 1855; Henry T. Patten, December 10, 1866; Arthur F. Holder, October 2, 1868; James MeCance, May 10, 1869; Leonidas M. McCance, January 10, 1884; Edwin N. Bryan, January 19, 1887, and Edgar M. Bryan, February 12, 1887, under whom the office was discontinued November 22, 1887. The office was re-established on October 17, 1892, with George R. Teter, postmaster, who served until the office was finally discontinued on March 31, 1903.

UTics. An inland hamlet at the cross highways in the northwest corner of section 6 of Harrisburg Township, now extending into section I of Washington Township. It was founded June 9, 1857, by John Whetsel. It was probably directly or indirectly named for Utica, Oneida County, New York, which in turn was named for Utica, the 
ancient city in Africa. Over twenty places in the United States have this name.

The post office of .Utica, Van Buren County, Iowa, was established December 4, 1849, with the appointment of Robert Brownfield, postmaster. His successors were: John Whetsel, date undecipherable; David Johnston, May 4, 1861; Theodore B. Rowley, March 17, 1864; Peter S. Sagerty, February 27, 1865; Eli A. Guess, February 9, 1866; Jacob Spraker, A pril 12, 1869; W. Faulkner, December 1, 1880; George Howard, May 21, J886; Kittie Miller, May 31, 1889; Kittie Spray, February 17, 1893; Willis A. Whitlow, March 27, 1894; George B. Rowe, November 18, 1899, and William H. 'Teal, December 19, 1901, who served until the office was discontinued on July 15, 1903.

ValdeY. The name of a rural school on the south side of section 16 of Chequest Township in district Number 3. As the school is in the valley of an aftuent of Chequest Creek the name is locally descriptive. By Andreas' Allas, 1875, the school site wats formerly at the forks of the highway in the north central part of the section, one-fourth mile south of Providence Baptist Church. The school district has the same name as the school.

VarLex. The name of a rural school on the nortl side and in the northwestern part of south section 11 of Des Moines Township, about threc miles west of the village of Mount Sterling. The school site is at the junction of the valleys of Valley Branch and Fox River. This makes the name locally descriptive. 'The school district, known as Number 5, also has the name Valley.

VALIEY BrANCH. A small stream rising in the southern part of south section $\tilde{5}$ of Des Moines Township, in the vicinity of Niles Station, with southern branches from sections 9 and 15, runs southeast and northeast to Fox River in the central part of south section 2 of the same townslip. The stream for its size has an unusually wide valley, hence its name is locally descriptive.

Vax Bunes. This township lies near the center of Van Buren County, south of Lick Creek and Union, west of Washington, north of Des Moines and Henry, and east of Chequest townships. It is quite irregular in shape but in the main comprises most of congressional township 69 north, range 10 west, with additions from surrounding townships. 'The township was named for the county in which it is situated and probably also for its pioneer village.

The congressional township 69 north, range 10 west, was constituted a civil township by order of the Board of County Commissioners in the organizing session held Junuary $6,184.1$. At the adjourned meeting of the board held February 9, 1841, the township was named Van Buren and it was ordered that the first meeting of the citizens was to be held in Keosauqua. Subsequent changes created the present boundaries.

Van Bunes. A pioneer village in section 36 of Van Buren 'Township. The site was a triangular piece of ground laid out in 1839 along 
the northwest side of the Des Moines River. The promoters hoped to secure the county seat and named their village after the county. The village soon became a part of Keosauqua, which. see. 'The name is retained by the township.

Verros. This township lies on the south side of Van Buren County, south of Henry, west of Farmington, and east of Des Moines townships. It comprises fractional parts of congressional townships 67 and 68 north, range 9 west. The township was apparently named for the village Vernon which is now in Henry 'Township, but was formerly in Vernon Township. According to George G. Wright: "Vernon Township was so named on the motion of a Mr. Babcock, at a meeting held at the house of A. 'Thomas for the purpose of agreeing upon a name. This township was almost the seat of the 'Missouri War'." 42

The congressional township 68 north, range 9 west, and fractional township 67 north, range 9 west, were constituted a civil township by order of the Board of County Commissioners in the organizing session held January 6, 1841. At the adjourned meeting of the Board held February 9, 184.1, the township was named Vernon and it was ordered that the first meeting of the citizens was to be lield at the house of James A. Brown. Later the northern portion was included in the newly created township of Henry.

Vernos. The village site was laid out in the northwestern and northeastern parts respectively of sections 1 and 2 of what is now Henry Township, south of the Des Moines River, opposite the village of Bentonsport. It was founded June 12, 1837, by Henry Smith, John Smith, S. C. Reed and Isaac Reed, and for a time it was called South Bentonsport. A post office was early established with Jolın M. Estes, postmaster. The village was probably named for Mount Vernon, the home of General George Washington, which in turn was named for Admiral Edward Vernon (1684-1746) of the British Navy. Lawrence Washington (elder brother of George) served under Vernon and named the estate in his honor, he then being the owner. 'The school district, Number 5, comprising parts of sections 1 to 3, is also named Vernon, after the village.

'The post office of Vernon, Van Buren County, Iowa, was established May 12, 1852, with the appointment of John M. Estes, postmaster. His successors were: Augustus Bailey, October 30, year undecipherable; John M. Estes, July 9, 1859; H. E. Pitkin, May 8, 1861; Henry L. Morrill, November 19, 1861; Milton O. Ketchum, January 6, 1865; Nelson Mallett, July 26, 1866; Thomas P. Henry, March 22, 1869; Kachariah P. Murray, October 29, 1869; David P. Wilson, December 14, 1871; Chauncey Booth, August 27, 1872; Edward Ware, October 2, 1872; Nelson Mallett, August 29, 1876; Mary E. Ehrman, November 19, 1878; W. 13. Pitley, December 10, 1878; Joel H. 'Tracey, January 10, 1879; Henry Ehrman, Octoher 5, 1883; Oliver H. P. A rmstrong, July 26, 1890; Harvey Robb, March 24, 1892; Susan E. Liggett, October 13,

42 G. G. Wright's Address, p. 13. 
1892; Susan E. Fulton, February 19, 1894; Hattie A. Ehrman, August 9, 1894; Susan Fulton, December 8, 1896, and Frank Scott, September 23, 1898, who served until the office was discontinued on March 31, 1903.

Versox Prairis. A locally descriptive name for a rural school in district Number 1 at the forks of the highway in the east central part of section 26 of Vernon 'lownship. The school district, comprising sections $25,26,35,36$, and south halves of 23 and 24 , is also known as Vernon Prairie. See Plat Book, 1897, page 30. 'The name is locally descriptive, being in Vernon l'ownship and on the prairie.

Vesser Crewk. A small stream coming from Davis County, crossing the northwestern part of section 18 of Village lownship and reaching the Des Moines River in the southwest central part of section $\%$. It was probably named for a local resident.

Vildage. This township is in the northwest corner of Van Buren County, west of lick Creck and north of Chequest townships. It comprises congressional township 70 north, range 11 west. $A$ number of Indian villages were in this region and the white settlers established several of their own. The name of the township is apparently locally descriptive because of the former presence of Indian villages.

The congressional township $\gamma_{0}$ north, ringe 11 west, was constituted a civil township by order of the Board of County Commissioners at an adjourned meeting held February 9, 184.1. The board named the township Village and ordered that the first meeting of the eitizens be held at the house of John Saylor.

Wasmoveros. 'This township is in the central part of Van Buren County, south of Union, west of Harrisburg, north of Henry, and east of Van Buren townships, its south border being on the Des Moines River. It comprises a fractional part, the four eastern tiers of sections, of congressional township 69 north, range 9 west, with a small addition from township 68 . The township - was named in honor of General George Washington (1732-1799), first president (1789-1797) of the United States.

The congressional township 69 north, range 9 west, was constituted a civil township by order of the Board of County Commissioners in the organizing session held January 6,1841 . At the adjourned meeting of the board held February 9, 1841, the township was named Washington and it was ordered that the first meeting of the citizens was to be held at the house of William Sumons.

Wasingros. The name of a rural school in the northwestern corner of section 33 of Henry 'Township, nearly three miles east of the town of Keosauqua. The school district, Number 4, mostly comprising section 33, fractional 28, 29 and 32, south of the Des Moines River, is also named Washington. The district was originally a part of Washington 'Township, hence the name for the school and district.

Watrirows. A pioneer place founded May 26, 1837; laid off by John Crow, surveyor. The place has long since liapsed into a farming community. George G. Wright in his Address, page 16, says: "William 
Kendrick, one of the justices first appointed, laid out Watertown across [the Des Moines River] from Farmington. Jesse Wright bought him out, stopped the town, and dispersed the population."

Werster Ribge. 'The name of a rural school in the southwestern part of section 13 of Bonaparte 'Township, about three miles southeast of the village of Bonaparte. The schoolhouse site is on a ridge or divide between two streams. The school was so named by admirers of Daniel Webster (1782-1852), the American statesman; the second part of the name is locally descriptive.

West Hone Pranie. A rural school at the forks of the highway in the southeastern part of north section 18 of Des Moines Township, about three miles north and a mile east of the town of Cantril, and immediately across the highway north from Mount Zion M. P. church. Old maps indicate that formerly the schoolhouse site was in the north central part of section 20. A few years after 1895 the school district was divided and two new schoolhouses were built. One was called West Home Prairie as given above; the other one, known as East Home Prairie, is on the south side of the southeast quarter of section 21 of Des Moines Township, immediately east of Home Prairie church. See also Home Prairie.

White. 'The name of a rural school at the cross highways in the central part of section 29 of Cedar Township, in district Number 4, a mile and a half east and a mile and a half north of the hamlet of Utica. A nearby estate to the northwest is known as the "White School" Stock Farm, apparently so named after the local school. It is probable the school was so named for a local resident.

Whrte. The name of a rural school at the forks of the highway in the northwestern part of section 27 of Lick Creek Township. The township hall is across the highway south from the school. The school was apparently named for a local resident.

Whire. The name of a rural school in the southeastern part of section 19 of Van Buren Township, three miles west and a half mile north of the hamlet of Pittsburg. The school was probably named for a local resident.

White Chapel. The name of a rural Methodist Episcopal church on the highway in the southern part of the southwestern quarter of section 21 of Lick Creek Township.

Whits Esx. The name of a rural Free Methodist church in the west central part of section 30 of Village 'Township. It was named after the grove of white elm (Clmus americana) trees in the vicinity.

White OAK. The name of a rural school in the southeastern corner of section 30 of Farmington Township. The school site is a grove of white oak trees and Whiteoak Creek is nearby. The school was named after the creek. The school district, Number 4, comprising sections 29 to 32 , is also named white Oak.

Whiteonk Crenc. This is the name of a small stream which rises in the northeastern part of section 22 of Vernon Township, runs south- 
east to Indian Creek in the northeastern part of section 5 of Farmington Township. 'The creek is named for the groves of white oak (Quercus aiba) trees which occur along its course.

Whirtes. The name of a pioneer school built in 1842 in the vicinity of the village of Portland (later Leando). The school received its name from Walter Whitten on whose farm the schoolhouse site was situated. ${ }^{43}$

WILEY. The name of a rural school in the southeastern corner of section 27 of Des Moines Township. It was apparently named for James Wiley, an early resident of the same section. A later resident was Robert Wiley, who owned most of the southeast quarter of section 27 and on whose farm the schoolhouse site was situated. See Plat Book, 1897, page 9 .

WILITIS. A former post office and a hamlet in section 1 of Vernon Township at Willits' Station on the Chicago, Burlington and Quincy Railroad. The station was established on the farm of Eli W. Willits, an emigrant and native of Wayne County, Indiana, born October 17, 1838, moved to Van Buren County in the fall of 1842 . The station was named for him. The post office was known as Willits and was established with Albert S. Willits (a brother of E. W. Willits), postmaster, and it was apparently named for the postmaster. The name is sometimes misspelled Willets. The U. S. soil map, 1917, erroneously spells the name Willitt.

The post office of Willits, Van Buren County, Iowa, was established March 5, 1872, with the appointment of Albert Willits, postmaster, under whom the post office was discontinued February 10, 1873. The office was re-established January 30,1874 , with the appointment of Andrew J. Hultgram, postmaster, who served until the office was again discontinued October 24, 1879. The office was again re-established January 30, 1882, with Israel B. Chamberlain, postmaster. His successor was Eli W. Willits, May 14, 1887, under whom the office was discontinued August 5, 1893 . 'The office was re-established February 19, 1894, with Philip Eich, postmaster. His successor was John M. Page, March 3, 1894, under whom the office was finally discontinued October 4, 1895.

Willuts. The name of a rural school in district Number 6 at the forks of the highway on the south side of the southwest quarter of south section 1 of Vernon 'Township, about a quarter mile south of Willits Station. The school district, comprising south sections 1, 2, 11 and 12 , is also known as Willits. The name of the school and district. is directly for Willits Station and indirectly for Eli W. Willits and Albert S. Willits (brothers), early residents and prominent farmers of the district.

Wirsosvmas. A former inland post office on the south side of section 9 of Cedar 'Township. T'The office may have been numed for a local resident but more likely for Henry Wilson (1812-1875), statesman

43 Ibid., p. I6. 
and vice president (1873-1875) of the United States, candidate at the time of the naming.4 Haskell's map, 1876, gives the name as Wilson.

The post office of Wilsonville, Van Buren County, Iowa, was established May 22, 1872, with the appointment of Isaiah Harlan, postmaster. His successors were: Francis M. Harlan, July 15, 1875; Walter 'T. Dow, July 12, 1880; Francis M. Harlan, March 22, 1882; Albert F. Howard, November 2, 1887, and Isaiah Harlan, July 22, 1891, who served until the office was discontinued on April 15, 1901.

Winsonville. The name of a rural Christian church and a school on the south side of section 10 of Cedar 'Township in district Number 2. 'They were probably named for a local post office which was formerly situated less than a mile to the west.

Winchester. An inland hamlet at the cross roads near the center of section 21 of Union 'lownship. It was founded February 29, 1840, by John Reynolds and Jefferson Cox, proprietors. A post office was early established but has been discontinued. On Henn, Williams \& Co.'s map of 1855, Utica, Winchester and Birmingham are represented as being on the pioneer ridge road from Keokuk to Libertyville in Jefferson County. There have been at least six places in Ohio named Winchester and as many of the settlers in Union 'Township were from Ohio it is probable the village in Iowa was named for the one in Ohio. Many places in the United States have the name Winchester and, although a few were named for individuals, yet some of them were directly or indirectly named for Winchester, England.

The village of Winchester, Iowa, was laid out in nine blocks, the central one, number 5 , being the public square. The streets east and west were North, Jefferson, Washington, and South; the north and south were East, Main, Jackson, and West. These names are for noted personages or locally descriptive.

Winchester, the capital of Hampslire, Fngland, is on the River Itchen, sixty-six miles southwest of London. Before the Roman invasion the ancient Britons had a city here which they called Caer Gwont, White City. The invading Romans made it a station witl the name Venta Belgarum, the Venta of the Belgae. The Saxon invaders at the end of the fifth century transformed the name Venla into Winte and named the town Winte-cerster, the City of the Winte. From this comes the modern name Winchester.

The post office of Winchester, Van Buren County, Iowa, was established July 22, 1840, with the appointment of Abriham S. Holgate, postmaster. His successors were: Adonijah Panish, January 21, 1848; John H. Day, November 8, 1849; Asa Smith, July 14, 1853; Ezra S. Rand, May 11, 1854; Winfield S. Whitaker, December 30, 1856; 'Thomas A. Williamson, March 12, 1858; John M. Whitaker, May 31, 1858; David S. Huber, January 11, 1860; Sarah Huber, May 4, year undecipherable; Ezra S. Rand, May 6, 1864; Nathan W. Crane, March 19,

44 Wilsonville was named for James Faulkner Wilson of Fairfield, member of Congress from the First District from 1863 to 1800 , later U. S. Sentitor.-E.R.H. 
1867; A. A. Fry, January 28, 1868; Adam K. Bechtel, March 22, 1880; Richard Workman, March 20, 1882; Hiram G. Christler, January 24, 1890; Minerva Hawbaker, April 21, 1893; Sarah F. Hawbaker, February 4, 1899; Mary F. Whitcanack, April 30, 1900; George C. Mendenhall, May 18, 1901, and Hiram G. Christler, June 22, 1901, who served until the office was discontinued on March 31, 1903.

WoLF Branch. A small creck rising in the central part of section 27 of Vernon 'Township, runs southeast to Indian Creek in the southeastern part of section 2. The stream was apparently named for James M. Wolf, an early settler, residing in the vicinity of the stream, in section 34 .

Wooss. 'The name of a rural schiool of joint district Number 9 on the west side of section 30 of Harrisburg Township, about two miles northeast of the village of Bentonsport. It was named for Alexander H. Woods, an early resident and large landowner in the vicinity. Mr. Woods was born August 11, 1808, near Wheeling, West Virginia; lived in Ohio and Michigan. He married a darghter of William Meek, the builder of the Bonaparte mill and dam. Mr. Woods came to Van Buren County in the spring of 1837 and settled in Harrisburg Township. ${ }^{45}$

Woop's Mrlus. An early name for Mount Sterling, which see. "A State road was established, in 1847, from Wood's Mills, in Van Buren County, to Bloomfield, in Davis County. John Hale, of Van Buren, James Hawkins and Reason Wilkerson, of Davis County, Commissioners. Ordered to meet the first Monday in May." "se

Zaxesvilue. [Note: Lanesville, as listed earlier in this article by Dr. Fitzpatrick, and by any whom he may have followed, should have been Zanesville. 'The name came from Zanesville, Ohio, at which place was born and brought up J. H. McVeigh, on whose land the post office was kept, and who was the second postmaster of Zanesville post office. This was for some time after its establishment the post office of the subscriber.-E.R.H.]

ZION. A rural Methodist Episcopal church on the west side of the northwest quarter of section 8 of Van Buren Township, about four miles west of the hamlet of Kilbourne.

Zrox. A rural I..utheran church in the northeast corner of section 24, of Village Township, a mile east and a mile north of the hamlet of Douds Leando and nearly half a mile east of the hamlet of Business Corners. 'This church and the preceding one were dedicated in memory of the biblical name Zion, one of the hills of the city of Jerusalem, Palestine, though the name is often applied to the city itself. 'The name Zion comes from the Hebrew word l'siyon, meaning sunny or fort. Of the several hills on which Jerusalem was built Zion is the largest and in many respects it has been regarded as the most interesting.

45 Hist. of Van. Buren Co., 1878, p. 606; Plat Book, 1897, p. 11.

th Hist. of Van. Buren. Co., 1878, p. 391 


\section{SUMMARY}

The total number of names occurring in Van Buren County, Iowa, is 248. Of these 52 may be considered repetitions, thus giving a net total of 196 different names. The repetitions, however, usually name different places.

Of these names, 95, slightly more than 38 per cent, are locally descriptive. These comprise by far the largest group. 'The names of the next largest group number 58, nearly 24 per cent, and are in honor of local, pioneer settlers. Twenty-six names are in honor of prominent men, over ten per cent of the whole number. Twenty-two names, slightly less than nine per cent, are transferred ones from eastern states or a foreign country. There are fourtcen names that may be termed biblical, over five per cent. There are nine ethical names which convey ideals of the settlers, nearly four per cent. There are eight miscellaneous names, over three per cent. Only five names, over two per cent, are for animals, and the same number refer to the former Indian inhabitants. The remainder, nearly three per cent, includes nicknames, three, and unusual names, three.

The locally descriptive names make an interesting study. Of the ninety-five such names, twenty of them are of sylvan origin; that is, places with trees about them or in their vicinities. In this class are schools: Ash Grove, Brush College (two of them), Elm, Elm Grove, Hickory, Hickory Grove, Oak Hill, Red Oak, White Elm and White Oak; creeks as: Big Cedar, Cedar, Little Cedar and White Oak; churches as: Hickory Grove, Oak Grove and Church Elm, the latter a meeting place. There are also Oakland, a townsite, and Oak Point, a post office.

Eight places were named after nearby creeks or rivers. These are, schools: Bear Creek and Indian Creek; townships: Cedar, Cliequest, Des Moines and Lick Creek, and p'aces: Des Moines City and Lick Creek, the latter a post office.

Besides the above-mentioned schools there are twenty-two others with locally descriptive names. 'These are: Big Four, Brick, Brown Cottage, Business Corners, Chicken Ridge, Fairview, Flat Rock, Mount Sterling, Niles, North Lebanon, North Star, Pleasant Plain, Prairie Corners, Prairie Queen, Ridgc, South Lebanon, Stone, Summit, Union, Valley (two of them), and Vernon Prairie.

Sixteen creeks or rivers have locally descriptive names. These are: Brushy Fork, Copper, Des Moines, Honey, Indian, L.ick, Little, Little Fox, Little Lick, Mud (two of them), Potters Branch, Rock (two of them), South Fork and Valley Branch. To these may be added the one lake, Silver Lake.

Places, localities, or post offices with locally descriptive names are: Business Corners, Farmington State Park, Home, Independent, Indian Prairie, Iowa City, Irish Bend, Lanesville, I.ongview, Mount Sterling, New Lexington, New Market, Pleasant Hill, Portoro, Rising Sun, South Keosauqua, Stockport, Summit, Union Corners, Village and Watertown, twenty-one of them. 
Churches with miscellaneous, locally descriptive names are: Center Chapel, Christian, Cumberland Presbyterian, East Union, Harrisburg, Home Prairie and Union, seven in number.

The local, pioneer settlers loom large in this survey. Twelve creeks were named after settlers, as: Bakers, Chequest, Coates, Ely's, Holcomb, Miles Branch, Reeds, Seights, Stump, Thatcher's, Vesser and Wolf Branch. Twenty-eight schools honored men, each one being in the immediate neighborhood of the school bearing his name. Witness: Benjamin, Bradford, Canfield, Crum, Ellis, Gray, Guthrie, Horn, Jones, Leech, Leffler, McSurley, Mathas, Miller, Nixon, Rosser, Russell (two of them), Spencer, Swiers, Taylor, white (three of them), Whitten, Wiley, Willits and Woods. Fifteen places or localities recall to mind former residents, as: Baker's Point, Boyer Station, Brattain's Grove, Cantril, Doud's Station, Ely's Ford, Harrisburg (the abortive village), McVeigh, Meeks Mills, Parkersville, Siglers Mill, Stumptown, Upton, Willits and Wood's Mills. Three churches are apparently for local people, as: Millers Clapel, Storey Chapel and White Chapel.

Of the twenty-six places, directly or indircetly named in honor of noted men, one notes a varied list. Presidents reccived recognition in the following ways: Garfield, a school; Jackson, a township; Pierce, the hamlet, Pierceville; 'Thomas Jefferson, a school; Van Buren, county, township and a defunct village, and Washington, a township, school and its district. Statesmen are thus recalled: Benton, a village; Franklin, two schools; Tom Payne, a school; Wilson, a village, school and church; and Webster, a school. Here, too, may be included Lacey, for whom Lacey-Keosauqua State Park was in part named. Noted generals are: Bonaparte, a town and a township, and also the defunct hamlet Nipoleon; Henry, a township, and Sheridan, a post office. Niles, Postmaster General, has a hamlet; Kilbourne, the railroad builder, a village; Girard, the philanthropist, a school, and Black Hawk, the Sauk leader, a defunct hamlet. Only nineteen individuals, not a formidable list, and in some places the honor is indirect, in which cases the p'acenames are really locally descriptive.

The transferred names number twenty-two, some of which are indirectly or directly locally descriptive. Most of the names in some way are connected with the old homes of the pioneers, towns and villages in the eastern part of the United States. $A$ very few may directly and all apparently are indirectly, more or less remotely, derived from England. Here belong the following hamlets or villages, some of which no longer exist: Alexandra, Birmingham, Columbus, Farmington, Gainsborough, Harrisburg, Lexington, Mechanicsburg, Milton, Philadelphia, Pittsburg, Plymouth, Portland, Rochester, Selma, Utica, Vernon and Winchester. The townships belonging here are: Farmington, Harrisburg and Vernon. There is also the creek Lexington.

The religious life of the community is reflected in fourteen names of biblical origin. These names are: Bethel, two churches; Egypt, a school; Lebanon, a hamlet; Mount Moriah, a church; Mount Zion, a 
village, a church and a school; Olive Branch, a school; Palestine, a hamlet; Providence, a church; Salem, a school, and Zion, two churches.

The ideals of the community are noticeable in such names as: Enterprise, Eureka, Harmony and Hopewell, schools; Salubria, a beneficent community, and Union, a township, a post office and a church.

Names referring to the Indians make a poor showing. There are a Fox river, Fox island and a Fox post office in memory of the aboriginal inhabitants. There is also Iowaville, on the former site of a village of the Iowa Indians. Then there is Keosauqua, a name more or less of Indian origin. Three other names which might have been included, viz., Indian Creek, a stream and a school, and Indian Prairie, a post office, were placed in the locally descriptive list. There is also the mongrel name, Chequest, which is really neither Indian nor English. From this it appears that the Indians affected but little the life of the settlers, the former being mostly gone when the latter came.

Unusual names are few. There are Hedvolante, the name of an early township, as well as its hamlet, and Pameko, an early post office, names apparently of uncertain origin and also unique. There are three nicknames: Hawkeye, a school; Hickory, a post office, and Dogtown, the local name of a hamlet.

Only a few names refer to animals. These are: Bear Creek, Coon Branch, and the avian names of Big Ducis Creek and Big Duck Pond, all self explanatory. With these may be included Big Duck Marsh.

The miscellaneous or unclassified names are: Centennial, two schools; Leando, village and school; Pioneer, a school; Star, a school; Summer, a creek, and Tug Fork, a creek.

A study of the local personal and transferred names conclusively shows that the early settlers of Van Buren County were overwhelmingly Americans of English ancestry. Only two or three names are discerned to be of Teutonic or other extraneous origin. It is also evident the settlers went to the business of naming places with the inborn directness characteristic of pioneers. There was no flummery, but there was modesty. The names were doubtless more fitly chosen than the meager records often indicate.

An examination of the list as a whole reveals an astonishing homogeneity of the entire county as a community. Notice the long list of locally descriptive names; all entered in various ways into the life and activities of the settlers. I.ocal pioneer settlers in every school district were selected by their neighbors for the highest honor they were able to give them. Even the prominent men outside whom the settlers honored, all in some way affected the life and aspirations of the local neighborhoods. The transferred names in the main reflect their attachments to their old homes. The biblical and ethical names give an insight into the emotions and ideals of the settlers. Even the few names referring to the Indians, animals, or even the nicknames in some way touched the life of the pioneers. This gives a total of 237 , or over 95.5 per cent of the entire number. Of the remainder there are eight mis- 
cellaneous or unclassified names. $\Lambda_{n}$ inspection readily indicates that most if not all are a part of the life of the community. 'This raises the percentage to nearly 98.8. The remaining three are unusual names. Were the record in all cases ample or complete there would in all probability be no exceptions, raising the already known, very high percentage to an even hundred.

\section{ADDENDA}

Big Foun. "The so-called Big Four school district was in fact the school district of Iowaville. I assume it was organized when Iowaville was still a thriving community, and included land in four different counties, namely, Van Buren, Jefferson, Wapello, and Davis. I think more of this district lay in Davis County than in any other. Van Buren was second and had the largest number of pupils as a rule and Jefferson third. Wapello contributed only a small part of the territory. There were timcs when more of the pupils lived in Davis County. My idea is that the name Big Four comes from the fact that the school district was an independent one lying in four different counties. The entire district of Iowaville, including additional land in Jefferson and Davis counties, is now a part of the consolidated school district of Selma."-A. I. Heminger in letter.

The above account gives much additional information and does not in fact contradict any statement made by the author. On consulting one of the early atlases of Van Buren County it will be observed that there was a time when the Big Four schoolhouse was in the north central part of section 6 of Village Township and the school district comprised scetion 6 and portions of sections 5,7 , and 8 . But this time was long after the organization of the original district and some time before the creation of the present consolidated school district of Selma.

Beusir Coldise. There was another rural school with this name in the western part of Union Township, so named for the same reason as the others were.

Cexter Chaper. For many years this church was known as Brush Chapel, a locally descriptive name.

Down's STrTrox. "This has always been the name of the town since it was laid off by Eliab Doud and his brother. The name of the post office has been changed from time to time. When Portland, which is just across the river, made application for a post office, the department. did not care to constitute a new post office under that name. So the nume Leander was submitted to the department which name was later contracted to leando. After the briclge was constructed the post office department united the two under the name of Douds-Leando and then later, in order to shorten the name, reduced it to Douds. The names of the two villages still remain, the one as Doud's Station, the other Leando. Both are in the same consolidated school district and the name of the school district is Douds-Leando."-A. L. Heminger in letter.

Hartronn. A projected townsite with this name was platted in north section 5 of Des Moines Township, in the vicinity where the Gray schoolhouse now is. 
Hedvolastr. Mr. A. L. Heminger writes: "The village apparently was located about where the township hall is now, in the section [28 of Des Moines Township] south of the Home Prairie church."

Hexry. It is well known that Henry County, Iowa, was named in honor of General James Daugherty Henry. Henry Township in Van Buren County, however, was probably not so named. Mr. A. I. Heminger comments as follows: "Henry 'Township, according to the best of my information, was named for Sylvester Henry, who was a member of the County Board of Supervisors from Vernon Township when the township was divided into two townships, Henry and Vernon. Sylvester Henry lived in the north part of the township which was given that name [Henry] after the division."

In the History of Van Buren County, 1878, page 367, the name is given as S. S. Henry. He was a member of the County Board of Supervisors from the old Vernon 'lownship for the years 1868-1870.

Krosavqus. The entire first paragraph on this town in this contribution was, with the exception of the first sentence and a later one in brackets, a quotation from the History of Van Buren County, 1878, pages 467-468. The quotation was indicated and the reference given. The account was included in this article for whatever it might be worth. So far as the literature is concerned the account has remained unchallenged. Mr. A. L. Heminger, attorney, of Keosauqua, Iowa, comments on this paragraph as follows:

"It is hardly correct to say that the town was laid off in 1839 , though it was resurveyed at that time, so as to include the major portion, as it is referred to as a diamond-shaped piece of land, which in fact was rectangular, and was the northwest one-fourth of section 36 . Van Buren was laid off in that part of the southwest one-fourth of section 36 which is northwest of the Des Moines river. Des Moines was laid off in that part of the northeast one-fourth of section 36 which lics northwest of the river and the southeast corner of the northwest one-fourth touches the river just about the center of the section, and of course the direction of the river made an acute angle at the points of these river lots where they come together."

"On August 6, 1838, it appears of record that Des Moines and Van Buren united under one name, Keosauqua. The plat of Van Buren was filed May 17, 1837, and appears of record in Deed Record A, page 14. It does not appear from the records here that Robert Taylor was one of the proprietors, though he and Meshach Sigler and James Manning secmed to have been associated with the enterprise at one time."

"On the 10th day of September, 1836, the question of the location of a county seat was submitted to the voters and two towns were contending for the same, Bentonsport and Keosauqua, and Keosauqua received the majority of the vote. Keosauqua having been determined as the county seat, by resolution of the board of supervisors, the county entered the northwest one-fourth of section 36, and under the authority of Johṇ Carnes, Charles Dạis, and John Saylor, county commissioners, 
- Van Buren was resurveyed, including a large part of the county quarter, under the name of Keosauqua. The town plat of Des Moines has never been changed but of course it is included within the limits of Keosauqua, and the plat was filed at about the same time."

Zaxisvilus. The word Lanesville was used on the authority of the U. S. Post Office Department, manifestly a clerical error. The old records are in longhand and one form of the old fashioned capital $Z$ is easily mistaken for a capital L, hence the error. Zanesville, Muskingum County, Ohio, was named for Ebenezer Zane, who, with John McIntire, founded the city.

\section{BIBLIOGR A PHY 47}

Lea, Albert M. Notes on the Wisconsin Territory; particularly with reference to the Iowa District, or Black Hawk Purchase. Philadelphia: H. S. 'Tanner. 1836. P. 53, map.

Plumbe, John. Sketches of Iowa and Wisconsin taken during a residence of three years in those territories. St. Louis: Chambers, Harris \& Knapp. 1839. Map.

Galland, Isaac. Galland's Iowa Emigrant: containing a map, and general descriptions of Iowa Territory. Chillicothe: Printed by Wm. C. Jones. 1840. Pp. 32, map.

Williams, Jesse. Map of the surveyed part of Iowa. New York. Published by J. H. Colton. 184.0.

Newhall, John B. Sketches of Iowa, or the emigrant's guide; [etc.] Published by J. H. Colton, New-York. 1841. Pp. 252, map.

Nicollet, I. N. Report intended to illustrate a map of the hydrographical basin of the Upper Mississippi River. Washington: Blair and Rives. 1843. Pp. 170, map.

Smith, J. Calvin. The western tourist, or emigrant's guide through the states of Ohio, Michigan, Indiana, Illinois, and Missouri, and the territories of Wisconsin and Iowa: [etc.] New York: Published by J. H. Colton, 1844. Pp. 119, map.

Newhall, J. B. A glimpse of Iowa in 1846; or, the emigrant's guide, and state directory; with a description of the new purchase: [etc.] Second edition. Burlington, Iowa. W. D. Skillman, publisher. 1846. Pp. 112.

Colton's township map of the state of Iowa [etc.] Published by J. H. Colton, No. 86 Cedar St., New York, 1852.

Smith, J. Calvin. The western tourist and emigrant's guide through the states of Ohio, Michigan, Indiana, Illinois, Missouri, Iowa, and Wisconsin, and the territories of Minesota (sic), Missouri, and Nebraska: being an accurate and concise description of each state and territory; and containing the routes and distances on the great lines of travel. [Etc.] New York: Published by J. H. Colton, No. 86 Cedar-Street. 1853. Pp. 89 of text and 24 of advertisements, map.

Ensign \& Thayer's travelers' guide through the states of Ohio,

47 The exact wording, spelling, punctuation, capitalization, etc., as shown on the title pages of the original works are bere followed. 
Michigan, Indianil, Illinois, Missouri, Iowa, and Wisconsin; with railroad, canal, stage, and steamboat routes; accompanied with a new map of the above states. New York: Ensign, Bridgman \& Fanning, 156 William street, corner of Ann, 1854. Pp. 33 and 2 of advertisements, map.

A township map of the state of Iowa [etc.] Published by Henn, Williams \& Co., Fairfield, Iowa, and by R. I.. Barnes, Philadelphia, N. E. corner of 7th \& Market Sts. 1854. Also edition of 1855.

Parker, N. Howe. Iowa as it is in 1855; a gazetteer for citizens, and a hand-book for emigrants, embracing a full description of the state of Iowa: [etc.] Chicago, Ill.: Keen and Lee. 1855. Pp. 264. The edition for 1856 appears to be only a page for page reprint. All the maps examined in the copies for 1855 or 1856 were inserted ones of Henn, Williams \& Co., 1855.

Colton's township map of the state of Iowa [etc.] Published by J. H. Colton and Co., 172 Williams St., New York, 1856.

Parker, Nathan H. The Iowa handbook, for 1856. With a new and correct map. Boston: John P. Jewett and Company. [Etc.] 1856. Pp. 188, map.

Parker, Nathan H. Iowa as it is in 1857; a gazetteer for citizens, and a hand-book for emigrants, embracing a full description of the state of Iowa: [etc.] New and revised edition. Chicago, Ill.: Keen \& Lee, 1857. Pp. 282.

Parker, Nathan HI. The Iowa handbook, for 1857. With a new and correct map. Boston: Published by John P. Jewett \& Co. [etc.] 1857. Pp. 188, map.

Hall, James, and J. D. Whitney. Report on the geological survey of the state of Iowa: embracing the results of investigations made during portions of the years $1855,56 \& 57$. Published by authority of the legislature of Iowa. 1858. 2 vols., map. The chapter on Van Buren County occupies pages 219-230. The map is dated 1857 .

G. Woolworth Colton's township map of the state of Iowa. 1862. Drawn, engraved \& published by G. Woolworth Colton, 18 Beekman St., New York. Mills Brothers, Des Moines, Iowa.

Hair, James 'T. Iowa State Gazetteer embracing descriptive and historical sketches of counties, cities, towns and villages [etc.] Chicago: Published by Bailey \& Hair, at the office of the city directory, 164 Clark Street. 1865. The chapter on Van Buren County was contributed by Charles Baldwin of Keosauqua.

Colton's sectional map of the state of Iowa, [etc.] Published by G. W. \& C. B. Colton, 172 William St., New York. 1868.

Wright, Geo. G. An address delivered before the Pioneer Association of Van Buren County, August 28th, 1872, at Keosauqua, Iowa. Keosauqua Republican Print. 1873. Pp. 36. A long extract is given in The History of Van Buren County, Iowa, 1878, pages 375-379.

Andreas, A. 'T. Illustrated historical atlas of the state of Iowa. Published by the Andreas Atlas Co. Lakeside building, Chicago, Ill. 
1875. Map of Van Buren County on page 246, history of the county on pages 411-412.

Haskell's new sectional and township map of Iowa compiled from the latest official sources. Published by O. C. Haskell \& Co., 64 Lake Street, Chicago, Ill. 1876.

McCrary, A. H., and Charles Baldwin. Pioneer addresses, 1875 and 1877. Delivered before the annual reunions, picnics and festivals of the Pioneer Association of Van Buren County, Iowa, at Keosauqua. Pamphlet. Keosauqua: 1878. Extracts are given in The History of Van Buren County, Iowa, 1878, pages 368-370, 373.

The history of Van Buren County, Iowa, containing a history of the county, its cities, towns, \&c., [etc.] Chicago: Western Historical Company, 1878. Pp. 606, map.

Map of Iowa prepared and printed for the Ratroad Commissioners to accompany their report for 1888 . Copyright, 1888, by Rand, MeNally \& Co., Chicago.

Portrait and Biographical Album of Jefferson and Van Buren Counties, Iowa. [Etc.] Chicago: Lake City Publishing Co. 1890. Pp. 664.

Railway map of Iowa prepared and printed for the Secretary of State, by order of the 'Twenty-fourth General Assembly, 1892. Copyright, 1892, by Rand, MeNally \& Co., Chicago.

Lippincott's Gazetteer of the World. A complete pronouncing gazetteer or geographical dictionary of the world, [etc.] Originally edited by Joseph Thomas. New revised edition. Philadelphia: J. B. Lippincott Company. 1893. Pp. 2894.

Gordon, C. H. Geology of Van Buren County. Iowa Geological Survey, vol. 4, pp. 199-254. 1895.

Plat book of Van Buren County, Iowa. Drawn from actual surveys and county records. By the North West Publishing Co. 1897. Eng. by Balliet \& Volk, 27 So. Sixth St. Phila. Folio, pp. 51.

Map of Iowa published by the Kenyon Printing \& Mfg. Co. for the Railroad Commissioners, to accompany their report. Des Moines, Iowa 1900 .

Map of Iowa prepared and printed for the Railroad Commissioners to accompany their report. The Kenyon Printing \& Mfg. Co., Des Moines. 1904.

Gannett, Henry. The origin of certain place names in the United States. Second edition. United States Geological Survey, Bulletin No. 258. Washington: Government Printing Office. 1905. Pp. 334.

Savage, T. E. Geological maip of Iowa [etc.]. Iowa Geological Survey. 1906.

Lounsbury, Clarence, and H. W. Reid. Soil survey of Van Buren County, Iowa. U. S. Department of Agriculture, Bureau of Soils. Washington: Government Printing Office. 1917.

Standard atlas of Van Buren County, Iowa, including a plat book of the villages, cities and townships of the county. [Etc.] Compiled and published by Geo. A. Ogle \& Co., publishers \& engravers. Chicago. 1918. Folio, pp. 63 with a supplement of $22 \mathrm{pp}$. 
Financial reports of Van Buren County, Iowa. First to twentyeighth, 1902-1929, issued 1903-1930.

Stump, Mary J. Correspondence with reference to the Stump family of Selma, Van Buren County, Iowa.

Harlan, E. R. Mauscript notes copied from the original record book of the Board of County Commissioners of Van Buren County.

Hodges, Cornelia C. County Superintendent of school of Van Buren County, Keosauqua. Correspondence, particularly with reference to the place-names Flat Rock, Franklin, Girard, Home Prairie, Mount Zion (in Des Moines Township), Prairie Queen, Stone, and Webster Ridge.

Pittman, E. F. Correspondence, particularly with reference to the place-names Eim, Mount Zion, West Home Prairie, etc., as well as correction of personal names.

Heminger, A. L. Correspondence, giving pertinent comments on various place-names as indicated in the text.

\section{RIVALRY OF BURLINGTON AND DAVENPORT}

The Sun stands up manfully for Davenport, and does not seem to relish our remarks about its insignificance. Abandoning the hope of having the legislature convene at that point the next session, it consoles itself with the reflection that ultimately the seat of government must be near them. This we grant, and believe; but it furnishes the executive with no good reason for assembling the people's representatives at that place now when about three-fourths of the population lies below it. The editor talks about Burlington "falling into decay." This is all fudge. The population of Burlington at this day is equal to the whole of Scott County.-Iozea Territorial Gazette, Burlington, I. T., August 25, 1838. (In the Newspaper Division of the Historical, Memorial and Art Department of Iowa.) 
Copyright of Annals of Iowa is the property of State of Iowa, by \& through the State Historical Society of Iowa and its content may not be copied or emailed to multiple sites or posted to a listserv without the copyright holder's express written permission. However, users may print, download, or email articles for individual use. 